\title{
REFORMA TRABALHISTA E OS MEIOS ALTERNATIVOS DE SOLUÇÃO DOS CONFLITOS DE INTERESSES TRABALHISTAS
}

\section{RESUMO}

\footnotetext{
${ }^{1}$ Professor Titular Concursado de Direito do Trabalho e Processo do Trabalho da Universidade do Estado de Minas Gerais (UEMG). Graduado em Direito pela Universidade de Ribeirão Preto (1999), pós-graduado em Direito do Trabalho pela Pontifícia Universidade Católica de Goiás (2006), e em Direito Tributário pelo Instituto Brasileiro de Direito Tributário (2010), Mestre em Direito Constitucional pela Universidade de Ribeirão Preto. Professor de Direito do Trabalho e Processo do Trabalho pela Unaerp. Autor do livro: "Reforma Trabalhista: flexibilização das normas sociais do trabalho", 2017, pela editora LTr. Contato: marcelo.braghini@uemg.br. http://lattes.cnpq.br/0758745102492628. 2. Professora designada do Curso de Direito da Universidade do Estado de Minas Gerais (UEMG). Doutora em Direito Constitucional pela Pontifícia Universidade Católica de São Paulo/SP (PUC/SP). Mestra em Direito, pela Instituição Toledo de Ensino em Bauru (ITE). Especialista em Justiça Constitucional pela Universidade de Pisa (Itália). Bacharela em Direito pelo Centro Universitário de São José do Rio Preto/SP (2002). Advogada inscrita na Ordem dos Advogados do Brasil - Secção de São Paulo - sob o n. 216.485. Líder do Grupo de Pesquisa, certificado pelo CNPQ: IRIS (Igualdade, Reconhecimento e Inclusão Social: Minorias e Grupos Vulneráveis). Tem experiência acadêmica-profissional em gestão de educação superior, tutoria em educação a distância e docência do ensino superior. Contato: andreiagarciamartin@ gmail.com. http://lattes.cnpq.br/5843968752917552.

${ }_{3}^{3}$ Professor Titular Concursado de Direito do Processual Civil da Universidade do Estado de Minas Gerais (UEMG). Advogado e professor universitário. Mestre em Direito. Especialista em direito público. É gerente geral jurídico do SEB - Sistema Educacional Brasileiro. Contato: ronaldo.filho@uemg.br. http://lattes.cnpq.br/3388063983886364.
} 
Com a promulgação da Lei $\mathrm{n}^{\circ}$ 13.467/17, que introduziu a Reforma Trabalhista no Brasil, foi possível destacar alguns eixos temáticos de conteúdo estrutural, e no âmbito procesual, sobressai a predileção do legislador infraconstitucional pelo fomento dos meios alternativos de solução dos conflitos trabalhistas, em especial o instituto jurídico da Arbitragem, em matéria trabalhista, superando a questão da natureza indisponível dos direitos trabalhistas. Ao mesmo tempo, passa a incentivar a transação extrajudicial dos direitos trabalhistas, com previsão de um procedimento específico, de jurisdição voluntária, garantindo-lhe o efeito de título executivo judicial.

Palavras-chave: Reforma Trabalhista; Meios Alternativos de Solução dos Conflitos de Intereses; Arbitragem; Homologação de Transação Extrajudicial.

\begin{abstract}
With the enactment of Law 13467/17, which introduced the Labor Reform in Brazil, it was possible to highlight some thematic axes with structural content, and in the procedural scope, the predilection of the infraconstitutional legislator for the promotion of alternative means of conflict resolution labor arbitration, in particular the Arbitration legal institute, in labor matters, overcoming the question of the unavailable nature of labor rights. At the same time, it encourages the extrajudicial transaction of labor rights, with a specific procedure, voluntary jurisdiction, guaranteeing the effect of a judicial enforcement order.
\end{abstract}

Keywords: Labor Reform; Alternative Means of Settlement of Conflicts of Interest; Arbitration; Approval of Extrajudicial Transaction.

\title{
1 INTRODUÇÃO
}

Não obstante a reforma da legislação trabalhista tenha sido retomada em período de grande turbulência econômica e política, pelo governo do Presidente Michel Temer, inegável a importância desta discussão no contexto das demais reformas estruturais do Estado, uma minirreforma, pretensão inicial do Projeto de Lei $\mathrm{n}^{\circ} 6.787 / 16$, posteriormente desfigurado na Câmara dos Deputados através de uma ampla reforma, que culminou com a promulgação da Lei $n^{\circ} 13.467 / 17$, não representa uma panacéia a todos os males, de qualquer modo, a almejada modernização do direito do trabalho através de uma agenda pró-mercado não deve representar a negação de uma regulamentação social adequada, que não seja um entrave aos níveis desejados de produtividade próprios do mundo contemporâneo.

A contextualização atual do direito do trabalho denota a necessidade de novas soluções para uma regulamentação mais eficiente da relação de poder estabelecida entre capital e trabalho, em especial pela crescente e inexorável informalidade do mercado do trabalho, pela crise de identidade vivenciada pelos Sindicatos, não havendo articulação institucional capaz de reverter os níveis de ocupação que decorrem do desemprego estrutural, sem deixar de considerar um movimento tecnológico sem precedentes com profundos reflexos nas estruturas econômicas já tradicionais, 
modelos de negócios que tradicionalmente sempre empregaram grandes contingentes de trabalhadores, e que passam a estar com os dias contados, dentro da dinâmica apresentada por uma economia disruptiva no contexto de uma $4^{\mathrm{a}}$ Revolução Industrial.

No plano político, com o fim da Guerra Fria, representada pela simbologia por detrás da queda do muro de Berlim, não há mais a polarização ideológica entre o socialismo e o capitalismo, o inviabilidade prática do primeiro o relegou ao campo da utopia, e o segundo passa a estar renovado pela vertente neoliberal, diante dos desequilíbrios orçamentários provocados pelo Estado Social (Welfare State), motivo pelo qual reforça a tese de desregulamentação no sentido da desarticulação do direito do trabalho, discutindo-se a necessidade de Estado suficiente forte para fazer prevalecer os direitos mínimos de proteção do trabalho, atrelados a fundamentalidade principiológica e valorativa construídos ao entorno da dignidade da pessoa humana, sem descuidar da força normativa dos princípios constitucionais.

Com o sepultamente da tese socialista, e como corolário direto da função social da propriedade, há o triunfo da socialidade, prevalência do interesses sociais da coletividade sobre aqueles meramente individuais, possibilitando, dentro de alguns limites, a ampliação do espaço da negociação coletiva no sentido da privatização do direito do trabalho, passando a exigir uma conduta ética no ambiente corporativo, que perpassa pela Teoria da Nova Empresarialidade, alinhada com uma maior responsabilidade social das empresas quanto ao equilíbrio da relação de trabalho, apresentando novas diretrizes, que rompem com a tendência paternalista decorrente da hipertrofia da legislação Estatal de proteção social do trabalhador, o que para alguns permitiria uma reformulação dogmática a partir da disfuncionalidade do sistema de proteção, exigindo uma releitura da teoria da hipossuficiência, com a maior aproximação ao modelo de regulamentação justrabalhista autônoma.

Todavia, não devemos nos descuidar da perspectiva histórica responsável pela construção do nosso atual modelo de proteção social, refletir a respeito dos erros e acertos, e compreender o próprio processo cultural responsável pela construção de nosso tecido social, não há fórmula mágica a ser imposta por organismos internacionais dentro da perspectiva neoliberal do consenso de Washington (equilíbrio orçamentário, direito do trabalho mínimo, privatizações, regimes previdenciários auto-sustentáveis etc), devemos ser intérpretes capazes de assegurar à Reforma Trabalhista, norma jurídica a ser extraída do texto prescritivo e frio da lei, uma justa compatibilidade com a efetividade dos direitos fundamentais de segunda 
dimensão, em especial pela visão pós-positivista, bem como captar a essência da reforma do Código Civil de 2.002, admitindo a construção doutrinária do Direito Civil Constitucional, uma vez que a guinada promovida nesta seara do direito esteve sustentada nos preceitos da: eticidade, socialidade e operabilidade.

Em nossa ótica, uma reforma trabalhista consistente deve reafirmar os valores essenciais do caput do art. $170 \mathrm{da} \mathrm{CF} / 88$, preservando na ordem econômica as dimensões do capitalismo idealizado no contexto do Estado Social, percepções admitidas no sentido de que a ação interventiva do Estado na seara da livre iniciativa deve ir até o ponto de resguardar as condições mínimas de trabalho digno, e pelo viés do moderno Direito Econômico, devemos abandonar por completo a visão obtusa de que um progresso social represente um obstáculo, um entrave, ao desenvolvimento econômico, devemos admitir o avanço deste sem o preço de anularmos o primeiro.

\footnotetext{
Estas são as diretrizes do modelo constitucional a ser preservado: "a ordem econômica, fundada na valorização do trabalho humano e na livre iniciativa, tem por fim assegurar a todos a existência digna, conforme os ditames da justiça social...".
}

Como meios alternativos de solução dos conflitos trabalhistas, eixo central do aspecto processual da Reforma Trabalhista, são instituídos novos institutos, como a arbitragem e a homologação de transação extrajudicial, superando a questão clássica da natureza dos direitos patrimoniais indisponíveis, que sempre esteve atrelada a teoria da hipossuficiência, corolário do princípio da proteção admitido como suporte fundamental do direito material do trabalho.

\section{SOLUÇÕES ALTERNATIVAS DOS CONFLITOS TRABALHITAS}

Para efeito da pacificação social, diante da vedação do exercício da autotutela por aquele que tenha sofrido um prejuízo em seus direitos e interesses, especialmente a partir da Revolução Francesa, em que foi reco- 
nhecida a separação dos poderes como meio de operacionalização do sistema de freios e contrapesos (check and balances) ${ }^{4}$, ao Poder Judiciário foi relegada a tarefa do exercício da função jurisdicional, consistente na aplicação da lei elaborada pelo Poder Legislativo aos conflitos de interesses que lhe são submetidos à apreciação, por tratar-se de função provocada, permitindo, assim, a consolidação do Estado de Direito (Rule of Law).

Diante da vedação do exercício arbitrário das próprias razões, imposição da vontade do mais forte sobre o mais fraco, crime tipificado no art. 345 do $\mathrm{CP}^{5}$, o Estado através da jurisdição passa a ser o detentor do monopólio da distribuição da Justiça, não obstante a tendência atual da adoção do sistema "multiportas", capaz de fortalecer e disseminar meios alternativos à solução dos conflitos do trabalho, diante da incapacidade técnica e administrativa da administração dos infindáveis conflitos em sociedade plural e de massas, que tenham por subproduto a morosidade da prestação jurisdicional, pregando a subsidiariedade do Poder Judiciário na solução dos conflitos de interesses em geral.

Com impactos diretos ao processo do trabalho contemporâneo, diante da excessiva judicialização dos conflitos trabalhistas no Brasil, discussão que ganha força e novos contornos com a Reforma Trabalhista aprovada pela Lei ${ }^{\circ}$ 13.467/17, novos instrumento alternativos de solução dos conflitos passam a valer com a necessidade da compatibilização da natureza dos direitos laborais em conflito, especificamente quanto à sua renunciabilidade, as regras do direito do trabalho são norteadas pela necessidade de preservação do interesse público que lhe são inerentes, representam a ordem pública retratada no art. 17 da LINDB, as declarações de vontade em geral não terão eficácia no Brasil todas as vezes que “... ofenderem a soberania nacional, a ordem pública e os bons costumes”.

Contudo, devemos colocar em perspectiva a questão de serem ou não os direitos trabalhistas irrenunciáveis ou intransacionáveis, e parecenos que Mauro Schiavi (2016, p. 42) estaria com razão quando afirma:

\footnotetext{
${ }^{4}$ Art. $2^{\circ}$ da CF: "São Poderes da União, independentes e harmônicos entre si, o Legislativo, o Executivo e o Judiciário".

${ }^{5}$ Art. 345 do CP:“Fazer justiça pelas próprias mãos, para satisfazer pretensão, embora legítima, salvo quando a lei o permite: Pena - detenção, de quinze dias a um mês, ou multa, além da pena correspondente à violência. Parágrafo único - Se não há emprego de violência, somente se procede mediante queixa".
} 
subordinação a que está sujeito o empregado, os Direitos Trabalhis-
tas, durante a vigência do contrato de trabalho, são irrenunciáveis,
como regra geral. Entretanto, uma vez cessados o vínculo de em-
prego e consequentemente o estado de subordinação, o empregado
pode renunciar e transacionar direitos, máxime estando na presença
de um órgão imparcial, como o Sindicato ou a Justiça do Trabalho.

Haveria a necessidade uma releitura principiológica do direito do trabalho, máxime a questão que permeia a trasacionabilidade deste conjunto de direitos, o que estaria por relativizar a questão da indisponibilidade ora tratada, está relacionada com a excessiva judicialização, justificando a proposição e fomento de meios alternativos para a solução dos conflitos de interesses na órbita trabalhista, não obstante não ser esta uma característica própria das lides laborais, mas como um traço comum das características socioculturais da nação.

Como iniciativa da incipiente de revitalização dos meios alternativos de solução de conflitos no âmbito trabalhista e mitigação dos efeitos liberatórios das quitações ofertadas fora do espectro da Justiça do Trabalho, nós ressaltamos as Comissões de Conciliação Prévia introduzidas no sistema a partir da edição da Lei ${ }^{\circ} 9.958 / 00$, a ser instituída no âmbito sindical ou da empresa, criando um verdadeiro rito de passagem ao prever a submissão prévia da demanda trabalhista à referida comissão, nos termos do art. 625-D da CLT, com a intenção de desafogar o aumento crescente das demandas trabalhistas.

As Comissões de Conciliação Prévia consistem em comissão paritária introduzida no sistema a partir da edição da Lei $n^{\circ}$ 9.958/00, a ser instituída no âmbito sindical ou da empresa, criando um verdadeiro rito de passagem prevendo a submissão prévia da demanda trabalhista à referida comissão, nos termos do art. 625-D da CLT, com a intenção de desafogar o aumento crescente das demandas trabalhistas, vejamos: "Art. 625-D. Qualquer demanda de natureza trabalhista será submetida à Comissão de Conciliação Prévia se, na localidade da prestação de serviços, houver sido instituída a Comissão no âmbito da empresa ou do sindicato da categoria. [...] $\S 2^{\circ}$ Não prosperando a conciliação, será fornecida ao empregado $e$ ao empregador declaração da tentativa conciliatória frustrada com a descrição de seu objeto, firmada pelos membros da Comissão, que deverá ser juntada à eventual reclamação trabalhista. $\$ 3^{\circ}$ Em caso de motivo relevante que impossibilite a observância do procedimento previsto no caput deste artigo, será a circunstância declarada na petição da ação intentada perante a Justiça do Trabalho". 
Contudo, através da decisão proferida em 13 de maio de 2009 pelo Supremo Tribunal Federal, afastou liminarmente a obrigatoriedade do rito de passagem dos conflitos trabalhistas pelas Comissões de Conciliação Prévia (art. 625-D, da CLT), por força do princípio do livre acesso ao Poder Judiciário (art. $5^{\circ}, \mathrm{XXV}$, da CF), na ADI n ${ }^{\circ} 2139$, houve intenso debate a respeito da matéria, para o Ministro Ayres Brito a solução: "estimula a conciliação e mantém uma tradição da Justiça Trabalhista de tentar a conciliação, sem sacrificar o direito universal de acesso à jurisdição”, por outro lado, e para que possamos ter uma noção exata da controvérsia através do debate de ideias, o Ministro Cezar Peluso afirma: "a postura do Corte, restringindo a possibilidade da tentativa obrigatória de conciliação, está na contramão da história, porque em vários outros países há obrigatoriedade do recurso às chamadas vias alternativas de resolução de conflitos, até porque o Poder Judiciário não tem dado conta suficiente da carga de processos", a tendência do processo moderno.

Persiste a discussão quanto à amplitude do art. 625-E, § único, da CLT, que trata da eficácia liberatória do termo de conciliação, com exceção das parcelas expressamente ressalvadas, titulo executivo extrajudicial: "aceita a conciliação, será lavrado termo assinado pelo empregado, pelo empregador ou seu proposto e pelos membros da Comissão, fornecendose cópia às partes. Parágrafo único. O termo de conciliação é título executivo extrajudicial e terá eficácia liberatória geral, exceto quanto às parcelas expressamente ressalvadas". Com a reforma trabalhista pela Lei $\mathrm{n}^{\circ}$ 13.467/17 a questão da eficácia liberatória passaria a estar superado, pelo fato de que a nova redação do art. 507-B da CLT admite a figura jurídica do "termo de quitação anual de obrigações trabalhistas", desde que com a intervenção obrigatória do Sindicato da categoria, e o § único do dispositivo legal em destaque, reforça a eficácia liberatória do termo ajustado em relação às "parcelas nele especificadas", o que poderá trazer uma alteração de paradigma revitalizando as CCP's. Entretanto, destacamos a construção jurisprudencial que respalda a edição da Súmula no 330 do TST 6 , que segundo a qual o recibo de quitação com a assistência Sindical tem

\footnotetext{
${ }^{6}$ Súmula no 330 do TST: “QUITAÇÃO. VALIDADE. A quitação passada pelo empregado, com assistência de entidade sindical de sua categoria, ao empregador, com observância dos requisitos exigidos nos parágrafos do art. 477 da CLT, tem eficácia liberatória em relação às parcelas expressamente consignadas no recibo, salvo se oposta ressalva expressa e especificada ao valor dado à parcela ou parcelas impugnadas. I - A quitação não abrange parcelas não consignadas no recibo de quitação e, conseqüentemente, seus reflexos em outras parcelas, ainda que estas constem desse recibo. II - Quanto a direitos que deveriam ter sido satisfeitos durante a vigência do contrato de trabalho, a quitação é válida em relação ao período expressamente consignado no recibo de quitação".
} 
efeito liberatório quanto às parcelas discriminadas, diferenças são admitidas diante de ressalva expressa do valor atrelado a parcela, e por tratar-se de recibo de quitação, que não pode ser uma peça ficcional, não abrange parcelas não discriminadas no recibo, por uma questão lógica, sem extrapolar os períodos abrangidos pelo recibo. Neste sentido, é a Súmula $\mathrm{n}^{\circ} 69$ do TRT da $4^{\mathrm{a}}$ Região ${ }^{7}$.

Sérgio Pinto Martins (2017, p. 111), dissertando a respeito dos limites da quitação, entende:

a quitação compreende apenas as parcelas e os valores pagos e não os títulos. Se não houve o pagamento integral, o empregado poderá reclamar eventuais diferenças ou até mesmo verbas que não foram pagas e que, portanto não foram quitadas. É claro que empregado poderá fazer ressalvas expressas em relação àquilo que não foi quitado. $\mathrm{O}$ fato de a lei fazer referência à ressalva expressa em nada modifica a questão, pois, mesmo que a ressalva não seja feita, não haverá quitação quanto à verba paga ou paga em valor inferior ao devido.

Os requisitos e efeitos da quitação encontram-se descritos no art. 320 do CC: "a quitação, que sempre poderá ser dada por instrumento particular, designará o valor e a espécie da dívida quitada, o nome do devedor, ou quem por este pagou, o tempo e o lugar do pagamento, com a assinatura do credor, ou do seu representante. Parágrafo único. Ainda sem os requisitos estabelecidos neste artigo valerá a quitação, se de seus termos ou das circunstâncias resultar haver sido paga a divida".

Essa tendência foi captada através do trabalho "Tribunal Multiportas: investindo no capital social para maximizar o sistema de solução de conflitos no Brasil", apresentado em 2012 pela Escola de Direito do Rio da Fundação Getúlio Vargas, segundo o qual há uma perceptível inovação transformadora dos meios alternativos de solução de conflitos no modelo do "Tribunal Multiportas", inserido em um projeto institucional desenvolvido pelo Professor Frank Sander da Harvard Law School, que permite o encaminhamento do caso ao fórum mais adequado para a resolução dos interesses em conflito, reconhecendo a especificidade de cada disputa, reservando ao Poder Judiciário um papel meramente subsidiário, não incentivando a excessiva judicialização das demandas trabalhistas.

\footnotetext{
${ }^{7}$ Súmula ${ }^{\circ} 69$ do TRT da $4{ }^{a}$ Região: TERMO DE CONCILIAÇÃO LAVRADO EM COMISSÃO DE CONCILIAÇÃO PRÉVIA. EFICÁCIA. EFEITOS. O termo de conciliação lavrado em comissão de conciliação prévia tem eficácia liberatória restrita aos valores das parcelas expressamente nele discriminadas, não constituindo óbice à postulação, em juízo, de diferenças dessas mesmas parcelas.
} 
Assim, o contexto contemporâneo nos permitiria revisitar a doutrina clássica de Américo Plá Rodriguez (2015, p. 149) a respeito da imperatividade da norma trabalhista, uma perspectiva normativa no sentido contrário ao da autonomia da vontade albergada pelo texto do Código de $\mathrm{Na}$ poleão, que no contexto político do liberalismo econômico propiciou o suporte jurídico para a prática rotineira de injustiças sociais, na seara da relação do trabalho. No campo do Direito do Trabalho a imperatividade de suas normas não impõe a negação da autonomia da vontade, diversamente, a livre manifestação da vontade do trabalhador depende do contingenciamento desta autonomia em determinadas etapas do contrato, em especial na sua formação e execução, momentos nos quais o estado de subordinação jurídica vem a ser sinônimo de despojamento dos direitos tutelares mínimos, sendo que o real sentido da expressão da "responsabilidade social" representaria a imposição voluntária de certos limites.

Na tramitação do Projeto de Lei $n^{\circ}$ 6.787/16 no Congresso Nacional, que tratava da Reforma Trabalhista, destacamos alguns pontos do substitutivo apresentado pelo relator Deputado Rogério Marinho (PSDB$\mathrm{RN}$ ), que seguiu tramitando no Senado Federal através do PLC no $38 / 17$, de relatoria do Senador Ricardo Ferraço (PSDB-ES), que teve a finalidade imediata de estancar a excessiva "litigiosidade das relações trabalhista" em duas frentes:

(i) Estímulo à conciliação extrajudicial: incentivo à composição previa entre capital e trabalho, através de um procedimento de jurisdição voluntária regulamentado nos artigos 855-A a 855-E da $\mathrm{CLT}^{8}$, sem criar qualquer obstáculo ao amplo acesso ao Poder Judiciário (ADIs 2139 e 2160 do STF que suspenderam a obrigatoriedade das Comissões de Conciliação Prévia prevista no art. 625-D da CLT), além do incentivo a arbitragem em matéria de direito individual do trabalho;

(ii) Superação do conceito da "litigância sem risco": exclusão da presunção de hipossuficiência, para permitir a condenação do reclamante em honorários advocatícios a serem pagos ao advogado da parte contrária na medida de sucumbência (art. 791-A, § $3^{\circ}$, da CLT ${ }^{9}$ ), cem como

\footnotetext{
${ }^{8}$ Art. 855-B. O processo de homologação de acordo extrajudicial terá início por petição conjunta, sendo obrigatória a representação das partes por advogado.

${ }^{9}$ Art, 791-A, $\S 4^{\circ}$, da CLT: "Vencido o beneficiário da justiça gratuita, desde que não tenha obtido em juízo, ainda que em outro processo, créditos capazes de suportar a despesa, as obrigações decorrentes de sua sucumbência ficarão sob condição suspensiva de exigibilidade e somente poderão ser executadas se, nos dois anos subsequentes ao trânsito em julgado da decisão que as certificou, o credor demonstrar que deixou de existir a situação de insuficiência de recursos que justificou a concessão de gratuidade, extinguindo-se, passado esse prazo, tais obrigações do beneficiário".
} 
a possibilidade de responder, também na hipótese de sucumbência, pelos honorários periciais devidos nas ações que tenham por objeto a insalubridade, periculosidade ou discussão a respeito das repercussões do acidente laboral (Art. 790-B da CLT ${ }^{10}$ ), regras de constitucionalidade duvidosa diante da restrição infraconstitucional do direito fundamental ligado a "assistência jurídica integral" expressão de inegável amplitude, como previsto no art. $5^{\circ}, \mathrm{LXXIV}$, da $\mathrm{CF}^{11}$.

Não apenas em relação ao Direito Material, mas também quanto ao Processual, durante a discussão da Reforma Trabalhista muito se discutiu a respeito da aplicação de instrumentos próprios do sistema da common law, e sobre ambos os aspectos não deve passar desapercebido as reflexões de Jorge Luiz Souto Maior (2000, p. 281-283) no sentido de que o direito corresponde a "narração histórica de um povo", o que exige um suporte cultural indispensável a sustentação da regulamentação subsequente, e no campo do Direito Material, a amplitude da regulamentação autônoma somente se justifica enquanto sindicatos e empregadores mantiverem esforços de boa-fé para solucionar seus dissídios sem o envolvimento do Estado, e especificamente a respeito da arbitragem, esta estaria disseminada no Modelo Americano diante da ausência de um Órgão Jurisdicional especializado em matéria trabalhista.

Por meio deste mesmo suporte cultural que permeia cada um dos sistemas, parece-nos um equívoco a tentativa de traçar um comparativo/paralelo entre a legislação nacional e americana, ou ainda, refletir a respeito da efetividade de cada um dos modelos utilizados para a solução dos conflitos de interesses trabalhistas, e neste ponto, é extremamente esclarecedor o artigo do Professor Cássio Casagrande com o título "A reforma trabalhista e o 'sonho americano",, publicado em 11 de junho de $2017^{12}$, que discute a realidade a respeito do "custo Brasil" diante dos seguintes aspectos: (i) inexistência de uma justiça laboral; e, (ii) excesso de judicialização das questões trabalhistas.

No tocante a inexistência de uma Justiça do Trabalho, diversamente do sistema da civil law (modelo romano germânico), o modelo de organização judiciária americana não segue o padrão de especialização em

\footnotetext{
${ }^{10}$ Art. 790-B da CLT "A responsabilidade pelo pagamento dos honorários periciais é da parte sucumbente na pretensão objeto da perícia, ainda que beneficiária da justiça gratuita".

${ }^{11}$ Art. 50, inciso LXXIV, da CF: "o Estado prestará assistência jurídica integral e gratuita aos que comprovarem insuficiência de recursos".

12 Disponível em: https://jota.info/artigos/a-reforma-trabalhista-e-o-sonho-americano-11062017, acesso em: 29/06/17.
} 
razão da matéria (rationae materiae), contudo, não deixamos de identificar uma legítima "jurisdição trabalhista" que trata de matérias similares aquelas discutidas nas cortes brasileiras, que através do modelo de precedentes permite a adoção de decisões judiciais dos Tribunais com efeito vinculante, este último efeito devido ao sistema stare decisis próprio da common law, não havendo justificativa, dentro da perspectiva do paralelo traçado entre os sistemas, para as críticas da excessiva sumularização do TST, que estaria excedendo aos limites do art. $2^{\circ}$ da $\mathrm{CF}$ ao representar inovação na ordem jurídica em determinadas matérias, sem correlação com as circunstâncias fáticas que lhe tenham justificado ( $\operatorname{art.} 926, \S 2^{\circ}$, do CPC), a título de exemplo, o citado articulista menciona a decisão da Suprema Corte dos EUA no caso Friedrichs v. California Teachers Associtation, tratando da constitucionalidade da fixação de contribuição assistencial compulsória em acordos coletivos.

E ainda, quanto à excessiva judicialização trabalhista no Brasil, que não difere da realidade vivenciada pelos demais Órgãos judiciários brasileiros, o que denota um completo descaso moral com o adimplemento voluntário das obrigações assumidas, seja na seara civil, consumeirista ou trabalhista, uma forma peculiar de organização do tecido social brasileiro, devendo ressaltar que no sistema americano a ação trabalhista típica é uma class action, uma ação coletiva promovidas por um único trabalhador que extrapola os seus efeitos em relação a todos aqueles que vivenciem idêntica situação de fato e de direito, a semelhança do instituto da "substituição processual", sem falar é claro na disseminação da arbitragem em solo americano.

Devemos lembrar que a excessiva judicialização tem raízes na deficiência institucional do Ministério do Trabalho e Emprego que não tem promovido de forma eficiente a fiscalização trabalhista, o que por si só seria capaz de prevenir a multiplicação dos conflitos em sua exata proporção, bem como pela quantidade insuficiente de ações promovidas a partir da substituição processual, das quais são legitimados o Ministério Público do Trabalho e os Sindicatos.

As críticas e alertas feitos por Amauri Mascaro Nascimento (2011, p. 154), na obra "Direito Contemporâneo do Trabalho", a respeito da judicialização dos conflitos nos parece extremamente esclarecedoras, para quem: 
qualquer conotação jurídica. Essa padece do defeito de não perceber que o direito, na sociedade, é a organização normativa dos comportamentos, o que mostra a inviabilidade dessa cogitação. Podese, no entanto, questionar a excessiva judicialização de alguns sistemas, quando não estruturado na adequada distribuição do peso que deve ter cada técnica compositiva, o que pode desequilibrar o sistema [...] a jurisdição é inafastável, mas não deve ser a única forma de composição. Um sistema que se proponha a resolver os conflitos resultantes dos contratos individuais do trabalho não pode prescindir da coparticipação de outros mecanismos aptos a reduzir sua carga, como as comissões sindicais de arbitragem, de mediação ou outros órgãos destinados a filtrar as questões antes de se apresentarem ao Judiciário.

\section{MEDIAÇÃO}

A mediação consiste em um meio de solução dos conflitos de interesses, e geralmente sua adoção é indicada nas situações jurídicas em que há um vínculo anterior entre as partes em conflito, trata-se de meio autônomo, pelo fato de não existir um terceiro (heterocomposição) impondo a solução do conflito às partes, o mediador restabelecer o diálogo entre as parte, permitindo que a aproximação provoque naturalmente a solução negociada, pautada em benefícios mútuos. Para Amauri Mascaro Nascimento, citado por Mauro Schiavi (2015, p. 40) "o mediador adota não o método impositivo, mas o persuasivo”. Este é o sentido adotado pelo art. $165, \S 3^{\circ}$, do CPC, de aplicação subsidiária ao processo do trabalho nos termos do art. 769 da CLT: "o mediador, que atuará preferencialmente nos casos em que houver vínculo anterior entre as partes, auxiliará aos interessados a compreender as questões e os interesses em conflito, de modo que eles possam, pelo restabelecimento da comunicação, identificar, por si próprios, soluções consensuais que gerem benefícios mútuos.

Para nós a natureza da mediação cinge-se aos demais meios de autocomposição, devido ao fato de que o mediador não detém poder de decisão para impor uma solução às partes, esta depende necessariamente da anuência de ambas as partes em conflito. Inegavelmente, o Código de Processo Civil aprovado através da Lei ${ }^{\circ} 13.105 / 15$ fomenta em diversas passagens a adoção da mediação, vejamos o art. $3^{\circ}$ do diploma em questão: "não se excluirá da apreciação jurisdicional ameaça ou lesão a direito. [...] $\$ 2^{\circ} O$ Estado promoverá, sempre que possível, a solução consensual dos conflitos. $\S 3^{\circ}$ A conciliação, a mediação e outros métodos de solução 
consensual de conflitos deverão ser estimulados por juízes, advogados, defensores públicos e membros do Ministério Público, inclusive no curso do processo judicial. [...] Art. 139. O juiz dirigirá o processo conforme as disposições deste Código, incumbindo-lhe: [...] V - promover, a qualquer tempo, a autocomposição, preferencialmente com auxílio de conciliadores e mediadores judiciais".

\section{ARBITRAGEM}

Diante da relação simétrica admitida no plano do Direito Coletivo do Trabalho, através da qual o trabalhador está representado pelo Sindicato da categoria profissional respectiva, sempre foi admitida a arbitragem como meio alternativo no art. $114, \S 1^{\circ}$, da $\mathrm{CF}^{13}$ apenas no plano coletivo, instrumento, até então incompatível com a assimetria da relação trabalhista analisada no plano meramente individual.

Analisando sua perspectiva evolutiva no direito pátrio, podemos dizer que antes da promulgação da Lei ${ }^{\circ}$ 13.467/17, não foi esta a opção política reconhecida no Brasil, ao destacarmos o veto presidencial ao art. 33 do NCPC/15 que autorizaria a conversão da ação individual em ação coletiva, seja pela "relevância social" do objeto debatido no processo, ou ainda, pela necessidade de uma solução uniforme à tutela coletiva que venha alcançar "relação jurídica plurilateral", bem como pelo veto ao $\S 4^{\circ}$, do art. $4^{\circ}$, na Lei $n^{\circ} 9.307 / 96$, lei de arbitragem, cuja redação proposta pela Lei $\mathrm{n}^{\circ}$ 13.129/15 permitiria ao “... empregado ocupante de cargo ou função de administrador ou de direção estatutário..." a pactuação de cláusula compromissória desde que o empregado tome a iniciativa de instituir a arbitragem ou concorde expressamente com a sua instituição, segundo a mensagem de veto $\mathrm{n}^{\circ} 162$, de 26 de maio de 2015 , essa possibilidade acabaria por “... realizar uma distinção indesejada entre empregados, além de recorrer a um termo não definido tecnicamente na legislação trabalhista, com isso, colocaria em risco a generalidade de trabalhadores que poderiam se ver submetidos ao processo arbitral".

A única hipótese de arbitragem em matéria trabalhista individual autorizada pelo legislador pátrio está vinculada à possibilidade da implan-

\footnotetext{
${ }^{13}$ Art. 114. Compete à Justiça do Trabalho processar e julgar: [...] § $1^{\circ}$ Frustrada a negociação coletiva, as partes poderão eleger árbitros.
} 
tação das Comissões de Conciliação Prévia pela Lei n ${ }^{\circ}$ 9.958/00, meio alternativo de solução de conflitos de interesses trabalhistas por excelência, ainda não judicializados, passível de ser instituído seja no âmbito intersindical ou empresarial (art. 652-A, parágrafo único, da CLT), meio de baixíssima eficácia, por ausência do seu Ethos de justificação, que no grego representa um padrão moral arraigado nos costume e nos traços comportamentais de cada povo, uma convergência encontrada nas críticas realizada em relação à possibilidade de ampliação do diálogo social através das negociações coletivas.

A Lei $n^{\circ} 13.467 / 17$ que trata da Reforma Trabalhista revoluciona a questão da arbitragem em matéria de direito individual do trabalho, até então vinculado a teoria da indisponibilidade das normas trabalhista, diante da carga imperativa das disposições legais que compõe o chamado conteúdo mínimo do contrato de trabalho. $\mathrm{O}$ art. 507-A da CLT ${ }^{14}$ passa a admitira a adoção de cláusula compromissória de arbitragem nos contratos individuais do trabalho cujo trabalhador perceba remuneração superior a 2 (duas) vezes o limite máximo estabelecido para os benefícios do Regime Geral da Previdência Social.

Sua funcionalidade depende necessariamente de um suporte cultural, moral e ético, e neste ponto, não há como deixar de sublinhar o posicionamento de Adalberto Simão Filho (2003, p. 47), que ao tratar da teoria da nova empresarialidade especificamente da eficiente solução de conflitos, utiliza-se das lições de Eduardo C. B. Bittar, para afirma que a solução ética dos conflitos é aquela que se extrai de forma pacífica das próprias partes interessadas, lastreada na real disposição de, por meios informais, alcançar a plenitude da resolução ponderada capaz de por fim a uma pendência interpessoal, sobre a orientação de preceitos éticos.

Contudo, a plena realização da arbitragem no direito individual do trabalho possui ao menos dois entraves, segundo a própria lei de regência da matéria, a Lei $n^{\circ}$ 9.307/96, representativa do marco jurídico da arbitragem no Brasil, vejamos:

(i) Natureza jurídica dos direitos trabalhistas: segundo o art. $1^{\circ}$, da Lei $\mathrm{n}^{\circ}$ 9.307/96 o procedimento da arbitragem, como modelo de jurisdi-

\footnotetext{
${ }^{14}$ Dispõe o art. 507-A da CLT, com redação pela Lei $\mathrm{n}^{\circ}$ 13.467/17: "Nos contratos individuais de trabalho cuja remuneração seja superior a duas vezes o limite máximo estabelecido para os benefícios do Regime Geral de Previdência Social, poderá ser pactuada cláusula compromissória de arbitragem, desde que por iniciativa do empregado ou mediante a sua concordância expressa, nos termos previstos na Lei no 9.307, de 23 de setembro de 1996”"
} 
ção privada, aplicar-se-á apenas em relação à solução dos litígios que tenham por objeto os direitos patrimoniais disponíveis, o que não é o caso do direito do trabalho segundo sua estrutura constitucional e evolução histórica. Parte da doutrina sustenta que indisponibilidade do direito está relacionada ao seu conteúdo, a proteção legal não pode ser renunciada a priori pela parte, apenas seus reflexos patrimoniais após o descumprimento das disposições legais, o que seria possível na homologação de transação extrajudicial, disposição de direitos posterior ao próprio contrato. O Enunciado $n^{\circ} 56$ da $2^{\text {a }}$ Jornada de Direito e Processo do Trabalho não reconhece a possibilidade da arbitragem em matéria de direito individual do trabalho, pelo caráter alimentar dos seus créditos, que atraem a regra de indisponibilidade e inderrogabilidade dos direitos trabalhistas.

Neste sentido, são as observações de Felipe Montenegro Mattos, na obra "Reforma Trabalhista: reflexões e críticas", coordenada por Nelson Mannrich, eis que:

encerrado o contrato de trabalho, os direitos nele previstos e eventualmente descumpridos serão objeto de negociação e reparação financeira, e não objeto de renúncia, como ocorre ordinariamente nos acordos firmados no curso de reclamações trabalhistas e homologados pelo Judiciário, com evidente transação de direitos.

(ii) Natureza jurídica contratual: o art. $4^{\circ}, \S 2^{\circ}$, da Lei $n^{\circ} 9.307 / 96$ contingencia os efeitos da cláusula compromissória no âmbito dos contratos de adesão, aquele no qual a assimetria entre os contratantes não permite a influência do aderente na formulação do conteúdo da relação contratual intencionada, traços de existência na própria gênese do contrato de trabalho, embora, as exigências da lei no sentido do "aderente tomar a iniciativa de instituir a arbitragem ou concordar, expressamente, com a sua instituição, desde que por escrito", tenham sido reproduzidas no texto celetista, que exige a iniciativa do empregado ou sua concordância expressa.

A viabilidade da regra, especialmente quanto à presença dos requisitos relacionados com a iniciativa do empregado, ou ainda, a sua expressa concordância, não passa ao largo do controle jurisdicional a respeito da existência de qualquer dos vícios do consentimento, a exemplo do dolo ou da coação, que possam viciar a manifestação da vontade indispensável para sua regularidade e legitimidade, sintetizada no âmbito trabalhista pela regra do art. $9^{\circ}$ da CLT. 
Ademais, o critério de elegibilidade previsto em lei restringe a incidência das cláusulas compromissórias de arbitragem nos contratos individuais do trabalho em que o titular venha a perceber remuneração superior a duas vezes ao limite (teto) os benefícios instituídos no âmbito da previdência social ${ }^{15}$, presunção legal de que o valor da remuneração seja termômetro suficiente e indicativo da maior simetria contratual, admitindo um poder de barganha do empregado na formulação do conteúdo do contrato, embora a base de cálculo eleita, diversa do salário, variável segundo contingências contratuais, não reflete verdade estabilidade econômica do contrato, sobre a perspectiva da contraprestação devida ao trabalhador, o que não lhe retira a presunção de vulnerabilidade social.

\section{HOMOLOGAÇÃO DA TRANSAÇÃO EXTRAJUDICIAL}

Antes mesmo da Reforma Trabalhista, prevendo a possibilidade da homologação da transação extrajudicial no art. 855-A da CLT, entendíamos haver compatibilidade do procedimento de jurisdição voluntária com o processo do trabalho, por força do art. 15 do CPC/15 e art. 769 da CLT, uma vez que a alteração legislativa com a promulgação da Lei $\mathrm{n}^{\circ}$ 13.015/15, Novo Código de Processo Civil, autorizava referido entendimento.

Este posicionamento tinha por suporte as lições de Mauro Schiavi (2015, p.43), que dissertava a respeito da possibilidade de adoção da transação extrajudicial nas lides trabalhistas que envolvam a "zona grise", relações de trabalho lato sensu em que há dúvida objetiva quanto à existência dos elementos do art. $2^{\circ}$ e $3^{\circ}$ da CLT, neste caso, a transação não corresponde a ato estrito de renúncia, ou seja, ato unilateral de despojamento de direitos reconhecidos em regra imperativa, a prevenção do litígio exige concessões recíprocas para uma relação jurídica controvertida ou duvidosa.

Reconhecemos nas palavras de Carlos Roberto Gonçalves (2013, p. 574) os elementos essenciais da transação extraídos do conceito legal do art. 840 do CC:

impendência ou existência de litígio ou de dúvidas sobre os direitos das partes, suscetíveis de serem desfeitos, já que o Código Civil, art. 840, refere-se à prevenção ou extinção de um litígio ou de uma

\footnotetext{
${ }^{15} \mathrm{O}$ teto da previdência social foi reajustado em $1^{\circ}$ de janeiro de 2017 para $\mathrm{R} \$ 5.531,31$ (Cinco mil quinhentos e trinta e um reais e trinta e um centavos).
} 
res dúbia entre os interessados, e é por meio da transação que se afastam as incertezas sobre um direito ou relação jurídica preexistente. Só pode haver transação quando os direitos sobre que versa forem litigiosos ou duvidosos.

Nas relações de trabalho em sentido lato, a problemática esteve sempre centrada na informalidade do distrato referente ao negocio jurídico estabelecido entre as partes, pela eternização do conflito dentro do prazo prescricional de 2 (dois) anos, já que eventual recibo de quitação não teria qualquer valor na extinção do litígio, a não ser a compensação do valor nominal pago para evitar-se o enriquecimento sem causa. Contudo, o art. 515, inciso III, do $\mathrm{CPC}^{16}$ passou a reconhecer como título executivo judicial a homologação da autocomposição extrajudicial, o que não dependeria da existência de lide, admitindo-se procedimento de jurisdição voluntária nos termos do art. 725 , VIII, do $\mathrm{CPC}^{17}$, com a pretendida força de coisa julgada, efeito próprio e natural de um título executivo judicial. Diante esta sistemática processual, o Enunciado $\mathrm{n}^{\circ} 63$ da $1^{\mathrm{a}}$ Jornada de Direito do Trabalho $^{18}$ admitia a compatibilidade da jurisdição voluntária com o processo do trabalho de forma restrita, restringia-se o procedimento às questões de ordem prática relacionadas com o contrato de trabalho, referentes à concessão de alvará judicial que permita o levantamento dos depósitos do FGTS e habilitação no seguro desemprego, com decisões em sentido contrário $^{19}$.

Conforme já discutido, a própria doutrina clássica ao analisar a imperatividade da norma trabalhista não estaria por imputar, na seara do Direito do Trabalho, a negação da autonomia privada da vontade do trabalhador, mesmo no plano individual, ter-se-ia apenas o seu contingenciamento nas etapas do contrato em que há maior incidência da subordinação

\footnotetext{
${ }^{16}$ Art. 515. São títulos executivos judiciais, cujo cumprimento dar-se-á de acordo com os artigos previstos neste Título: III - a decisão homologatória de autocomposição extrajudicial de qualquer natureza; ${ }^{17}$ Art. 725. Processar-se-á na forma estabelecida nesta Seção o pedido de: VIII - homologação de autocomposição extrajudicial, de qualquer natureza ou valor. ${ }^{18}$ Enunciado $n^{\circ} 63$ da $1^{a}$ Jornada de Direito do Trabalho. COMPETÊNCIA DA JUSTIÇA DO TRABALHO. PROCEDIMENTO DE JURISDIÇÃO VOLUNTÁRIA. LIBERAÇÃO DO FGTS E PAGAMENTO DO SEGURO-DESEMPREGO. Compete à Justiça do Trabalho, em procedimento de jurisdição voluntária, apreciar pedido de expedição de alvará para liberação do FGTS e de ordem judicial para pagamento do segurodesemprego, ainda que figurem como interessados os dependentes de exempregado falecido.

${ }^{19}$ SÚMULA N ${ }^{\circ} 31$ do TRT da $23^{a}$ Região: EXPEDIÇÃO DE ALVARÁ PARA LEVANTAMENTO DO FGTS. INCOMPETÊNCIA DA JUSTIÇA DO TRABALHO. A Justiça do Trabalho é incompetente para processar e julgar ação que vise a expedição de alvará judicial para levantamento do FGTS, visto não versar controvérsia oriunda da relação de trabalho, não se amoldando aos lindes do art. 114, I, da Constituição Federal. (TRT-IUJ-0000194-14.2015.5.23.0000).
} 
jurídica, em especial no momento da formação e da execução do contrato, possibilitando a transação extrajudicial após a extinção do contrato.

Portanto, este foi o caminho percorrido pelo legislador infraconstitucional com a edição da Lei $n^{\circ} 13.467 / 17$, a aplicabilidade do procedimento de jurisdição voluntária no âmbito do processo do trabalho passa a estar superada diante da previsão de capítulo próprio no âmbito do texto celetista, com a autorização taxativa no art. 652, "f" c/c art. 855-A da CLT de "processo de homologação de acordo extrajudicial", com seu procedimento definido no texto celetista ${ }^{20}$.

Resta saber se o procedimento especial de homologação da transação extrajudicial pode ser adotado em qualquer contexto contratual, envolvendo qualquer natureza de direitos laborais, independentemente do caráter alimentar dos seus créditos, cabendo apenas ao magistrado do trabalho o controle da disposição ou indisponibilidade dos direitos ventilados no objeto da ação, seguido o contorno da Súmula n 418 do TST: "MANDADO DE SEGURANÇA VISANDO À HOMOLOGAÇÃO DE ACORDO. A homologação de acordo constitui faculdade do juiz, inexistindo direito líquido e certo tutelável pela via do mandado de segurança", parecendo ser este o caminho apontado pelo Enunciado no 110 da $2^{\mathrm{a}}$ Jornada de Direito e Processo do Trabalho ${ }^{21}$, e talvez, seja este o caminho apontado pelo art. 723, § único, do CPC: “o juiz não é obrigado a observar critério de legalidade estrita, podendo adotar em cada caso a solução que considerar mais conveniente ou oportuna".

Para nós, conforme explicação aprofundada a respeito da redefinição do objeto do direito do trabalho, diante da crise vivenciada pelo critério da subordinação, a transação extrajudicial a ser homologada pela jus-

\footnotetext{
${ }^{20}$ Art. 855-B. O processo de homologação de acordo extrajudicial terá início por petição conjunta, sendo obrigatória a representação das partes por advogado.

$\S 1^{\circ}$ As partes não poderão ser representadas por advogado comum.

$\S 2^{\circ}$ Faculta-se ao trabalhador ser assistido pelo advogado do sindicato de sua categoria.

Art. 855-C. O disposto neste Capítulo não prejudica o prazo estabelecido no $\S 6^{\circ}$ do art. 477 desta Consolidação e não afasta a aplicação da multa prevista no $\S 8^{\circ}$ art. 477 desta Consolidação.

Art. 855-D. No prazo de quinze dias a contar da distribuição da petição, o juiz analisará o acordo, designará audiência se entender necessário e proferirá sentença.

Art. 855-E. A petição de homologação de acordo extrajudicial suspende o prazo prescricional da ação quanto aos direitos nela especificados.

Parágrafo único. O prazo prescricional voltará a fluir no dia útil seguinte ao do trânsito em julgado da decisão que negar a homologação do acordo.

${ }^{21}$ Enunciado $n^{\mathbf{0}} 110$ da $2^{\mathrm{a}}$ Jornada de Direito e Processo do Trabalho. Jurisdição voluntária. Acordo extrajudicial. Recusa à homologação. $\mathrm{O}$ juiz pode recusar a homologação do acordo, nos termos propostos, em decisão fundamentada.
} 
tiça especializada não deve ser procedimento padrão, apenas uma convivência harmônica com a alternativa do litígio representado pela reclamação trabalhista, já que o legislador com a Reforma Trabalhista não avança na regulamentação geral do trabalhador parassubordinado, continua arraigado aos paradigmas da $1^{\text {a }}$ Revolução Industrial, e dissociado da economia disrruptiva representada pela $4^{\mathrm{a}}$ Revolução Industrial, aquela comportava a dicotomia entre trabalho subordinado e autônomo, avançando apenas na reformulação do trabalhador autônomo ao inserir novos elementos ao art. 442-B da CLT. Logo, para nós o procedimento deverá ser adotado nas relações de trabalho em que as partes possam visualizar dúvidas quanto à existência dos elementos fático-jurídicos do art. $2^{\circ}$ e $3^{\circ}$ da CLT (subordinação, pessoalidade, não eventualidade e onerosidade).

De qualquer forma, o próprio empresariado que exige mudanças em direção a modernização da relação capital e trabalho, será responsável através de uma conduta ética de legitimar os novos meios de solução dos conflitos de interesses propostos no bojo da Reforma Trabalhista, especialmente quanto à jurisdição voluntária admitida na homologação das transações extrajudiciais, sob pena destas iniciativas terem o mesmo destino das Comissões de Conciliação Prévia, que inclusive poderiam ser revitalizadas em momentos de grandes transformações, dentro de um processo maior de revitalização das instituições Sindicais.

Algumas questões subsistem a esta nova modalidade de procedimento passível de solução dos conflitos trabalhistas, como a homologação parcial da avença, a possibilidade da interposição de Recurso Ordinário na hipótese de indeferimento, e principalmente, na esteira das discussões que permearam a Resolução $n^{\circ} 174$ do CSJT, quanto à necessidade da quitação prévia das verbas rescisórias, para que não se reconheça fórmula indireta de parcelamento de verbas rescisórias, e os efeitos restritos da quitação homologada em juízo alcançando apenas as parcelas discriminadas no termo pelos valores que lhe sejam correspondentes, para Felipe Montenegro Mattos (2018, p. 20) o que não estaria em consonância com o espírito da Reforma Trabalhista, para o autor deve "fazer prevalecer à vontade das partes. Verificando o juiz estar diante de verdadeira transação livre de vícios, que preveja a quitação plena do contrato de trabalho, impõe-se a este a homologação da avença”. 
Desta forma, estamos por construir uma jurisprudência consistente capaz de albergar estes novos institutos que tem a finalidade de estimular a composição dos conflitos de interesses trabalhista, o que acreditamos ser mais fácil em relação a homologação da transação extrajudicial, diante da atuação da Magistratura do Trabalho, sempre com a finalidade de coibir a prática de atos arbitrários, que corresponda a evidente abuso de direitos, hipótese de antijuridicidade prevista no art. 187 do CC, sem que a o ato abusivo subverta o fim econômico, e especialmente, em matéria de direito do trabalho, o fim social da norma.

Em relação a arbitragem, inicialmente admitida no sistema common law americano para conflitos empresariais, depois disseminados aos conflitos consumeristas, e posteriormente, trabalhistas, inegavelmente podemos predizer que haverá um recrudescimento na proteção dos direitos sociais do trabalho, segundo reportagem da revista The Economist, as indenizações fora da Justiça do Trabalho são inferiores àquelas reconhecidas pela justiça privada arbitral.

\section{REFERÊNCIAS BIBLIOGRÁFICAS}

ALEXY, Robert. Teoria dos direitos fundamentais. 2a ${ }^{\text {a }}$ ed. São Paulo: Malheiros, 2012.

BALERA, Wagner. O capitalismo humanista. Petrópolis: KBR, 2012.

BARROSO, Luis Roberto. Interpretação e Aplicação da Constituição Fundamentos de uma Dogmática Constitucional Transformadora. $4^{\mathrm{a}}$ ed. São Paulo: Saraiva, 2010.

. Curso de direito constitucional contemporâneo. 5ª ed. São Paulo: Saraiva, 2015.

BOMFIM, Vólia Cassar. Direito do trabalho. 11ª . ed. São Paulo: Método, 2015.

Comentários a reforma trabalhista. São Paulo: Método, 2017.

BONAVIDES, Paulo. Curso de Direito Constitucional. 27ª ed. São Paulo: Malheiros, 2012.

BRAGHINI, Marcelo. Reforma Trabalhista: flexibilização das normas sociais do trabalho. São Paulo: LTr, 2017.

DELGADO, Maurício Godinho. Curso de direito do trabalho. 13a . ed. São Paulo: LTr, 2014. A reforma trabalhista no brasil. São Paulo: LTr, 2017.

DWORKIN, Ronald. Levando os Direitos a Sério. São Paulo: Martins Fontes, 2011.

GRAU, Eros Roberto. A Ordem Econômica na Constituição de 1988. 16ª ed. São Paulo: Malheiros, 2013. 
HESSE, Konrad. A força normativa da constituição. Porto Alegre: Fabris, 2009.

IBRAHIM, Fábio Zambbitte. A Previdência Social no Estado Contemporâneo. Rio de Janeiro: Impetus, 2011.

Curso de Direito Previdenciário.14ª ed. Rio de Janeiro: Impetus, 2009.

MANNRICH, Nelson. A reforma do mercado de trabalho: a experiência italiana. São Paulo: LTr, 2010. A modernização do contrato de trabalho. São Paulo: LTr, 1998. . Reforma Trabalhista: reflexões e críticas. São Paulo: LTr, 2018.

PLÁ RODRIGUEZ, Américo. Princípios de direito do trabalho. 3a. ed. São Paulo: LTr, 2015.

PIOVESAN, Flávia. Direitos humanos e direito constitucional internacional. $8^{\mathrm{a}}$ ed. São Paulo: Saraiva, 2008.

REIS, Daniela Muradas. O princípio da vedação do retrocesso no direito do trabalho. São Paulo: LTr, 2010.

ROBORTELLA, Luiz Carlos Amorim. O moderno direito do trabalho. São Paulo: LTr, 1994.

LTr, 2010. . O direito do trabalho na empresa e na sociedade contemporânea. São Paulo:

ROMITA, Arion Sayão. Direitos fundamentais nas relações de trabalho. São Paulo: LTr, 2014.

SARMENTO, Daniel. Direitos Fundamentais e Relações Privadas. 2 ed. Rio de Janeiro: Lúmen Júris, 2008. 